\title{
最近の黄色ブドウ球菌感染症に関する検討
}

一臨床分離株の薬剤感受性と MRSA の頻度一

\begin{tabular}{|c|c|c|c|c|c|c|c|}
\hline \multicolumn{8}{|c|}{ 神戸大学医学部泌尿器科学教室（主任：守即貞夫教授） } \\
\hline 荒川 & 創一 & 高木 & 伸介 & 松井 & 隆 & 前田 & 浩志 \\
\hline 柯 & 昭仁 & 田 & 珠相 & 郷司 & 和男 & 岡田 & 弘 \\
\hline 本 & 修 & 守殿 & 貞夫 & & & & \\
\hline
\end{tabular}

\section{STUDIES ON RECENT CLINICALLY ISOLATED STAPHYLOCOCCUS AUREUS}

-Drug Susceptibility and Incidence of MRSA in Clinical Isolates-

Soichi Arakawa, Shinsuke Takagi, Takashi Matsui, Hiroshi Maeda, Shojin Ka, Syuso Den, Kazuo Gohji, Hiroshi Okada, Osamu Matsumoto and Sadao Kamidono

Department of Urology, Kobe University School of Medicine

(Director: Prof. S. Kamidono)

Susceptibility of various antimicrobial agents against clinically isolated Staphylococcus aureus was evaluated by Kirby Bauer methods. The incidence of MRSA (Methicillin cephem resistant Staphylococcus aureus) was also investigated. When S. aureus was isolated from urine, the clinical background of the case was further studied.

The results are listed below;

1) M1N0 showed the highest susceptibility rate (83.1\%) against 537 strains of S. aureus tested, followed by CMZ (63.7\%) and CET (63.5\%). The susceptibility rate of DMPPC was $41.9 \%$. The incidence of MRSA was $31.3 \%$.

2) In effusion, MRSA was most highly isolated (72.2\%).

3) S. aureus isolated from blood and sputa was relatively more resistant to $\beta$-lactams.

4) Strains from urine showed relatively high susceptibility rates. No MRSA was isolated from urine.

5) Thirteen out of twenty-four cases, whose urines were proven to be S. aureus positive, were polymicrobial infection patients.

要旨：当院において最近の各種臨床検体から分離された黄色ブドウ球菌につき，Kirby Bauer 法による ディスクにて薬剤感受性を検討した。少なくとも DMPPC, CET およびCMZ の三者に耐性すなわち MRSA (Methiclillin cephem resistant Staphylococcus aureus) と考克られるすのの割合を算出した. また，尿由来の黄色ブドウ球菌に関してはとの臨床的背景を検討した。全体（537株）の薬剤別感受性率 は, MINO が83.1\%と最も高く, 次いで CMZ (63.7\%), CET (63.5\%)の順であった. DMPPCでは

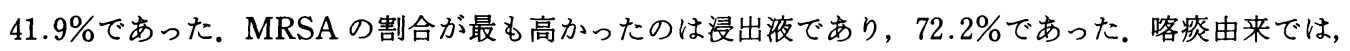
MRSA は37.8\%を占めていた。尿由来菌ではPCG, ABPC 以外には高感受性率であり, MRSA は 1 株 るみられなかった。眼科, 耳鼻咽喉科からの検体由来菌は，セフェム剂に比較的高感受性を示していた。 血液由来菌は全般に耐性傾向が強く, MRSA は41.9\%を占めていた。尿検体由来の本菌の分離形態は, 24 例中 13 例が複数菌であった。患者年齢の平均は約 40 歳であった。

\section{緒 雼}

近年, 黄色ブドウ球菌とりわけ Methicillin cephem resistant Staphylococcus aureus (MRSA) 感染症の増
加が指摘されている122). 本菌は強毒菌であり，ときと して敗血症や toxic shock syndrome(TSS) ${ }^{3)}$ な゙の致 死感染を引き起こすことが知られている。 
本菌感染症の対策を講ずる上で，その分離状況およ び抗菌薬感受性などを知ることは基本的に重要であ る.

今回，著者らの施設に抢ける最近の黄色ブドウ球菌 の検体別薬剂感受性を検討するとともに，特に尿由来 の本菌の特徵について解析を加えたので報告する。

\section{対象および方法}

（I）検体由来別黄色ブドゥ球菌の薬剂感受性率 神戸大学医学部附属病院にて昭和 62 年 1 月から 12 月 の 1 年間に分離された黄色ブドゥ球菌の薬剤感受性に つき, 各種検体由来別に検討した. 薬剤感受性は Kirby
Bauer 法（BBL 社：センシディスク）により, sensitive, intermediate, resistant のうち sensitive のみを 感受性とし, 他は耐性と判定した。

（II）尿検体由来黄色ブドウ球菌に関する検討

当科にて, 昭和 61 年 7 月から 62 年 6 月の 1 年間に尿 中から $10^{5} コ / \mathrm{ml}$ 以上分離された黄色ブドウ球菌につ き，その分離形態掞よび分離症例の臨床的背景につき 検討した。

\section{結果}

（I）検体由来別黄色ブドウ球菌の薬剤感受性率

成績は図中にグラフで示す。クラスディスクとして

困 1 黄色ブドゥ球菌の薬剤感受性（神大病院，1987，1月～12月）

一全検体一

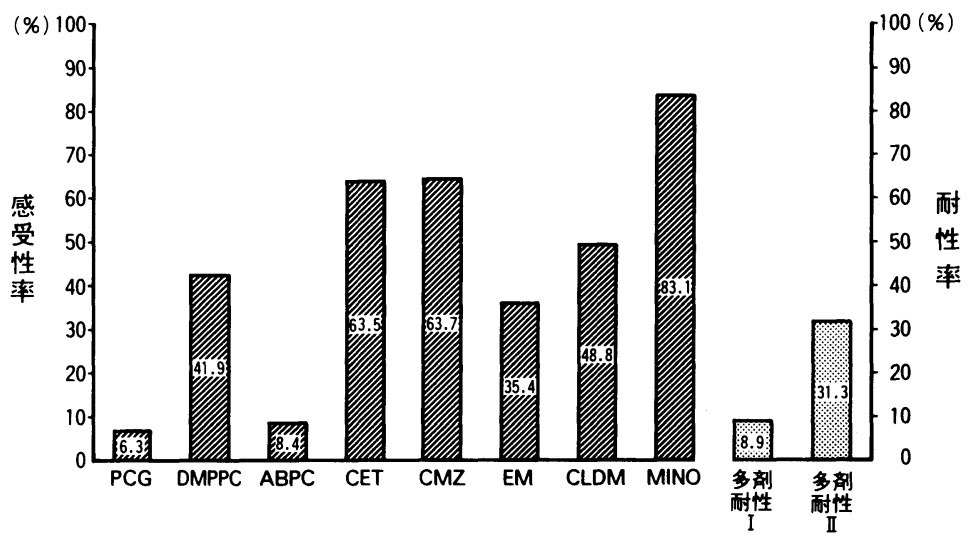

多剂耐性 I：全菜郕に耐性

多剂耐性 II：DMPPC, CET, CMZに耐性

図 2 黄色ブドウ球菌の薬剤感受性（神大病院，1987．1 月～12月）

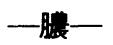

206 株
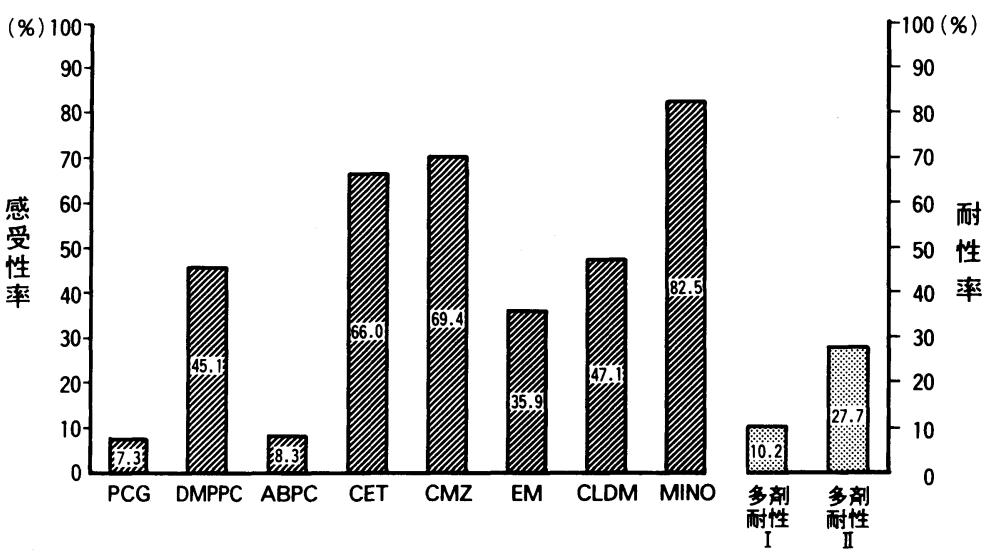
の各系統薬剂の感受性率とともに, 多剂耐性率を示し た。すなわち，多剤耐性 I とは被検全薬剤に耐性のもの の占める割合を，多剤耐性 II とは少なくともメチシリ ン (DMPPC), セファロチン (CET), セフメタン゙ー ル（CMZ）の 3 者に対して耐性のもの（すなわち， MRSA と考えられるもの) の割合を示している.

1）全体(図 1)：全検体あわせると537株の黄色ブド ウ球菌が分離されている。薬剤別感受性率は，MINO が83.1\%と最も高く, 次いで CMZ (63.7\%), CET (63.5\%)の順であった. PCG, ABPCの感受性率は低 く, DMPPCのそれは41.9\%であった。多剤耐性 I は $8.9 \%$ ，多剂耐性 II は $31.3 \%$ を占めていた。

2）膿（図 2）：膿からの分離は206株と最も多かっ
た。その薬剤感受性率は，全体に打けるそれらと類似 している。

3）浸出液（図 3）：耐性のものが多く，多剂耐性の ものの割合が多い.多剂耐性 II は $72.2 \%$ を占めている。

4）喀疢（図 4）: 全体での成績と，その分布などに おいても類似しており，多郕耐性 II は $37.8 \%$ である。

5）血液(図 5)：全体に比し，やや耐性傾向が強く, NINO で77.4\%, CMZ で54.8\%の感受性率であった。

6）尿（図 6)：PCG，ABPC を除くと，全般に高感 受性率を示しており，多剂耐性 I，IIいずれも該当す る菌株はなかった。

7) 結膜(図 7 )：MINO, CMZ, CET で高感受性率 を示している。

図 3 黄色ブドウ球菌の薬剤感受性（神大病院，1987，1月～12月）

一浸出液一

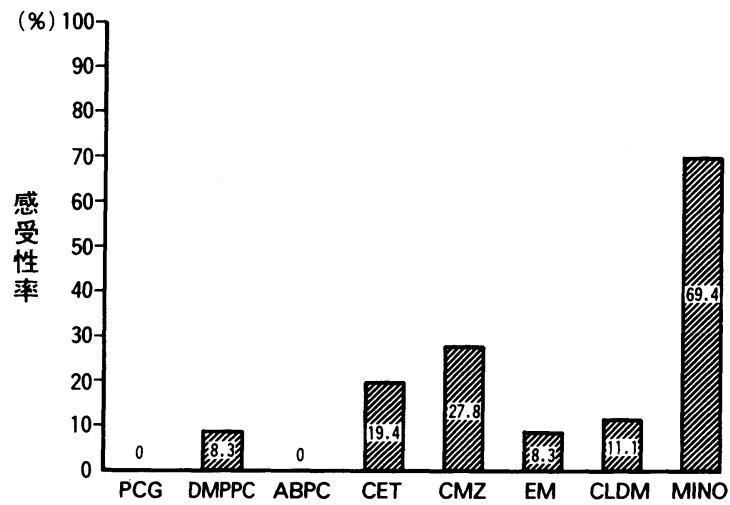

図 4 黄色ブドウ球菌の薬剤感受性（神大病院，1987．1月～12月）

\section{6 株}

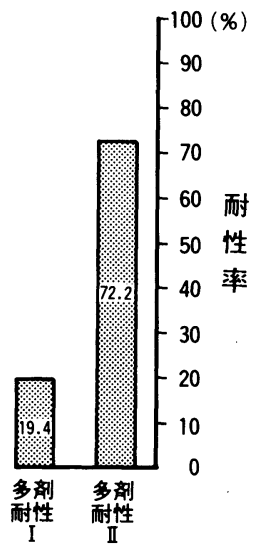

一喀痰一

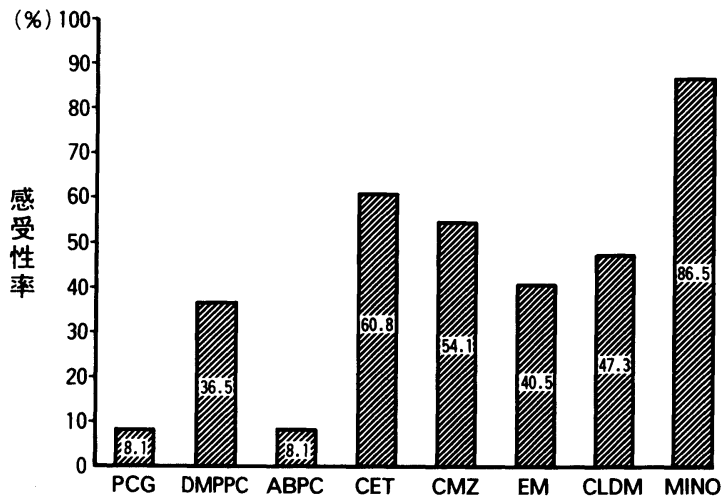

74 株

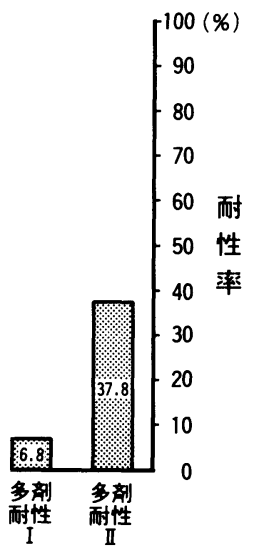


図 5 黄色ブドゥ球菌の薬剂感受性（神大病院，1987，1月１2月）

一血液一

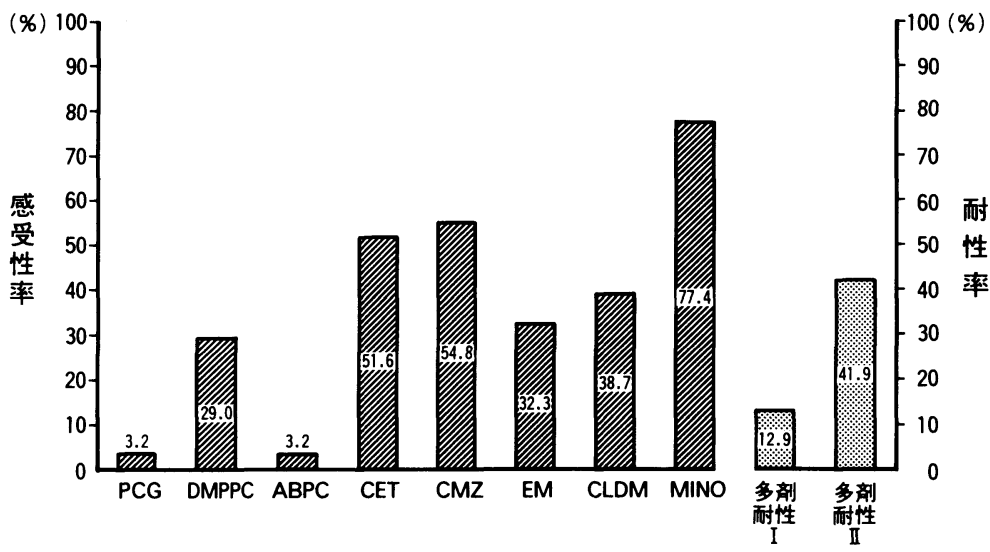

図 6 黄色ブドウ球菌の薬凨感受性（神大病院，1987，1月～12月）

一尿一

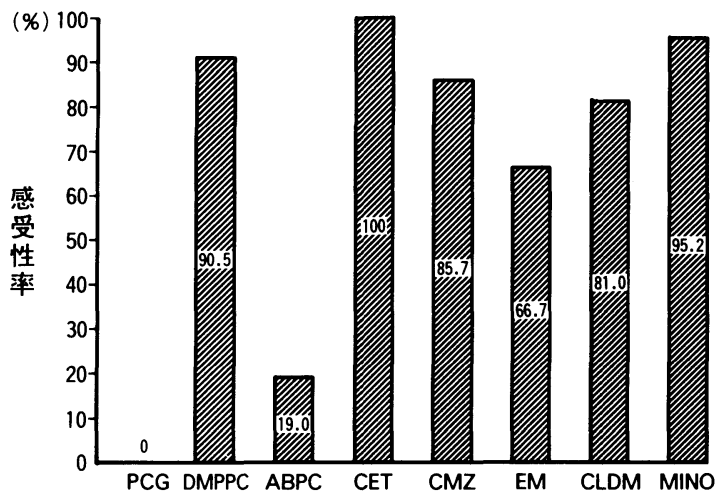

図 7 黄色ブドウ球菌の薬剤感受性（神大病院，1987，1月～12月）
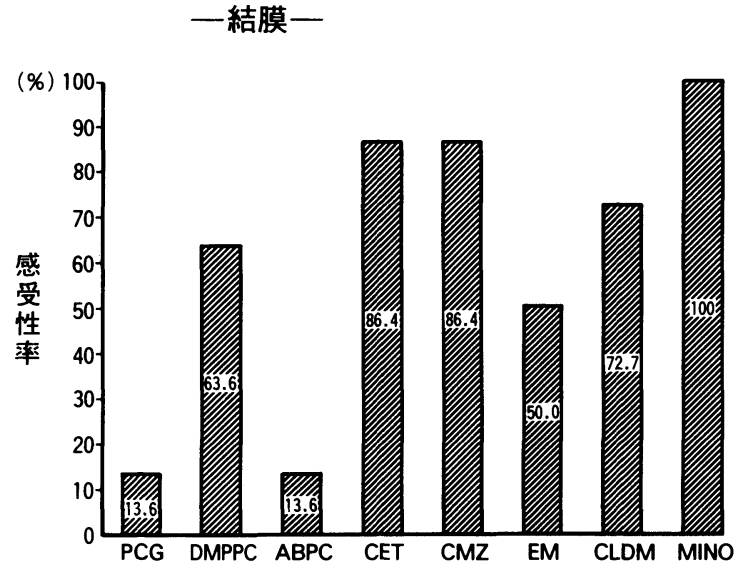

22 株

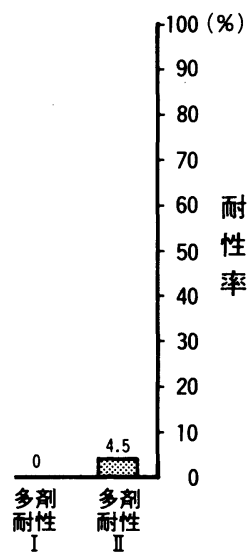


図 8 黄色ブドウ球菌の薬剤感受性（神大病院，1987，1月～12月）

-TPN先端—

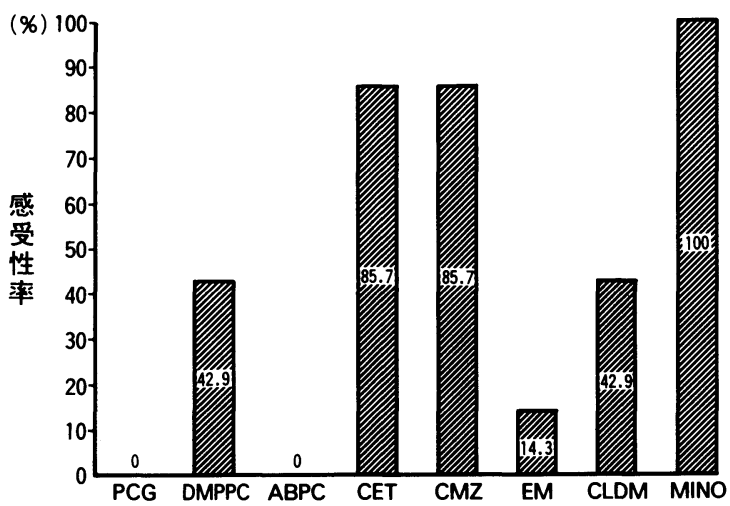

因 9 黄色ブドウ球菌の薬剤感受性（神大病院，1987，1月～12月）
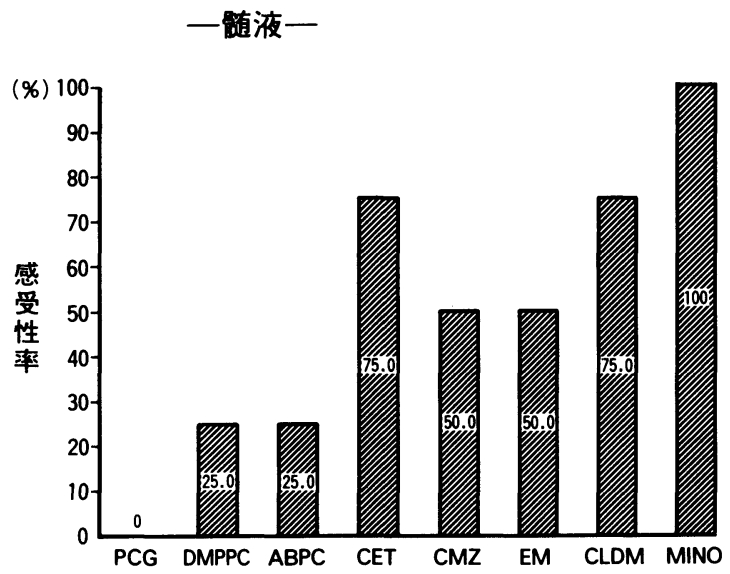

困10 黄色ブドウ球菌の薬剤感受性（神大病院，1987，1月～12月）

$$
\text { 一耳舅科検体一 }
$$

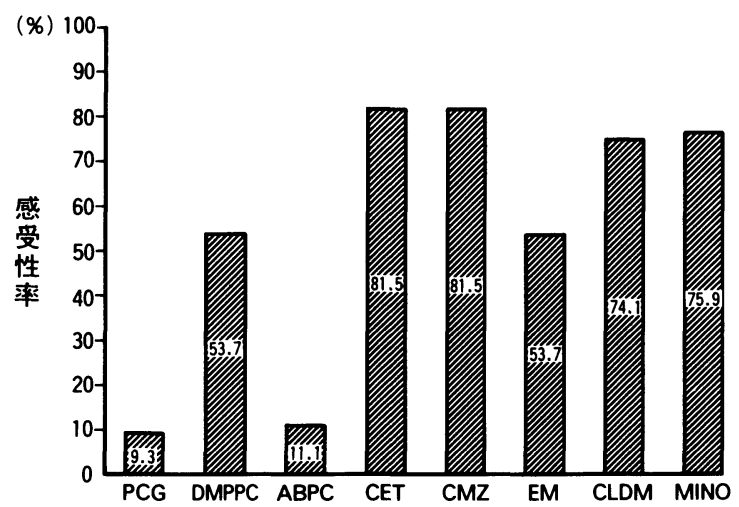

54 株

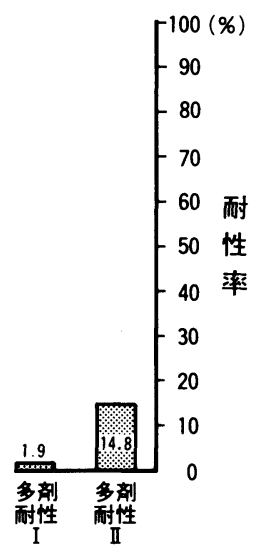


図11 黄色ブドゥ球菌の薬剤感受性（神大病院, 1987。1月～12月）

一その他一

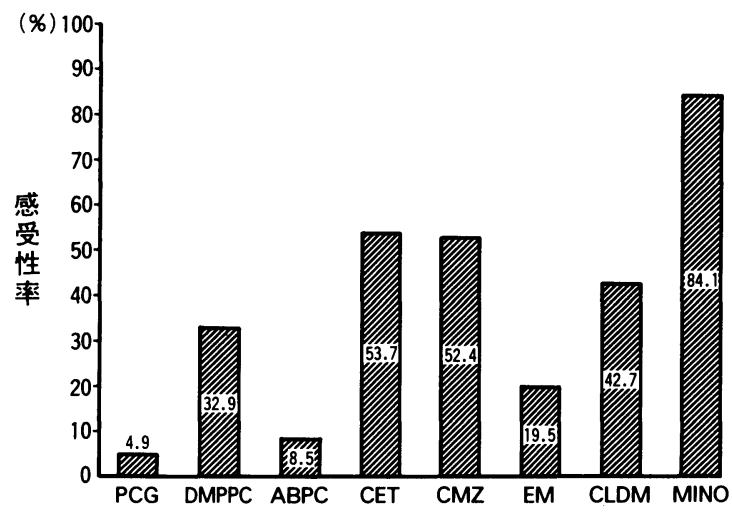

82 株

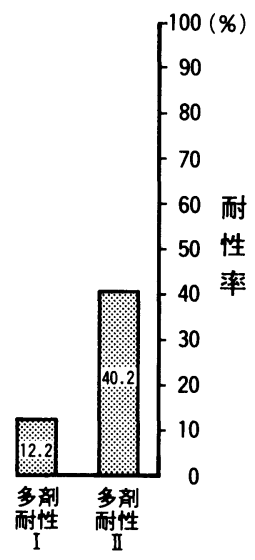

8）TPN 先端（図 8)：抜去された中心静脈栄養 (TPN) カテーテル先端から検出されたものも, MINO, CMZ, CET には良好な感受性率であった。

9）髄液（図 9）：4株のみであるが，5ち1株は多 剂耐性IIに属していた。

10）耳鼻咽喉科検体（図10）：CMZ，CET の感受性 率がすぐれていた。

11）その他（図11）：その他の検体由来の82株では, 全体に比し CMZ およびCET に対する感受性率がや や低かった。

（II）尿検体由来黄色ブドウ球菌に関する検討

1）分離形態（表 1)：24症例中, 11例で単独菌とし て，13例で複数菌の 1 つとして分離されていた．複数 菌のうち， 2 種分離は 9 例で, 同時分離菌は表皮ブド ウ球菌が 3 例と多く, 以下腸球菌, 緑膿菌などとなっ ている. 3 種分離の 1 例でも，グラム陽性菌との組み 合せが目立つ. 5 種のものも 1 例認められている.

2）分離症例の臨床的背景（表 2)

単独菌, 複数菌感染之も入院患者で多くみられ, 外 来で分離されたのは単独菌の 1 例のみであった。単独 菌としては泌尿器科以外での分離が多く, 複数菌は泌 尿器科と他科とが相半ばしており, 全体的に男性が多 かった. 患者年齢は, 平均するとほぼ40歳となるが, 幼小児から高齢者までに分布しており,一定の傾向は 認められなかった。

\section{考 察}

第二次世界大戦中から PCG が実用化され, 黄色ブ ドウ球菌感染症に効果を発揮したが, 数年後には penicillinase 産生菌すなわち PCG 耐性菌の増加)が
表 1 黄色ブドゥ球菌の尿中からの分離形態および同 時分離菌（神大病院，1986。7月～1987，6月）

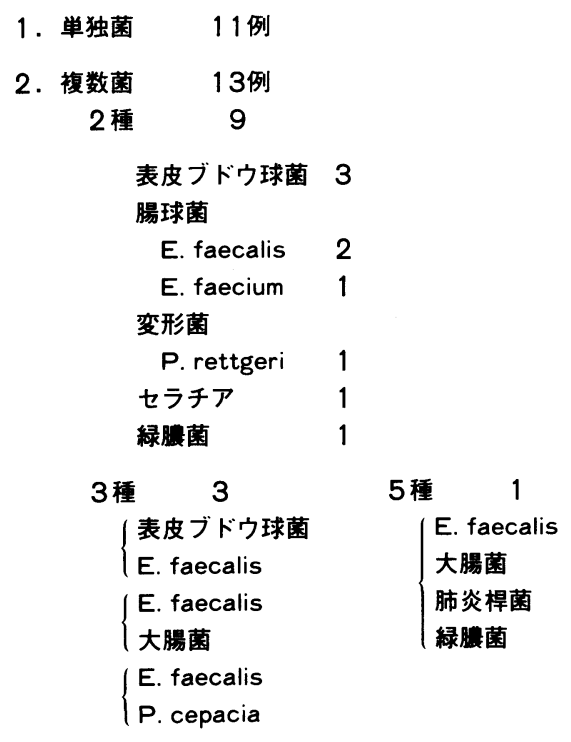

表 2 尿中黄色ブドウ球菌分離例の背景（神大病院， 1986. 7 月 1987. 6 月)

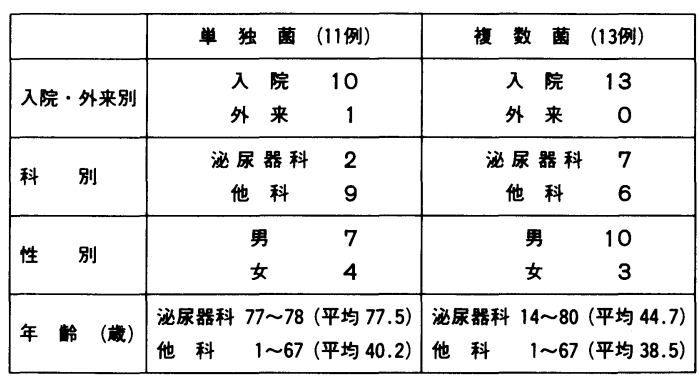


みられ，次いでテトラサイクリン，アクロライドなど に対する耐性プラスミドも有する多剂耐性株占が出現 してきた。1960年代に至り，メチシリン (DMPPC), クロキサシリン (MCIPC) などの半合成ペニシリンが 登場し, これらは多剤耐性黄色ブドウ球菌にも有効で あることから，問題は解決されたかに見えていた。し かし，1980年以降，第三世代セフェム剂が臨床に頻回 に使用されるようになったことに呼応し, 再び耐性黄 色ブドウ球菌が増加しはじめ, しかもその耐性は, 染 色体の変異による新しい機序によるもので, 広く $\beta$ lactam 剂に耐性を示すといら問題が close $\mathrm{up}^{6 / 28)}$ れてきている.

本菌（MRSA）の主たる耐性メカニズムは, 抗生剂 により誘導される新しい細胞壁合成酵素 PBP2'の存 在 ${ }^{199)}$ にあると考学られている。

今回著者らは, MRSAの分布状況を検討する目的 で, 最近の当院において各種臨床検体から分離された 黄色ブドウ球菌の薬剤感受性状況を調査した。 その結 果, クラスディスク中, 少なくとも DMPPC, CET, $\mathrm{CMZ}$ の 3 者に耐性のものすなわち MRSA と考兄ら れるものは，全体では $31.3 \%$ に認められ，全被検薬に 耐性のものは $8.9 \%$ 占めていた.

検体別では, 浸出液由来の本菌の耐性度が最も高く, これは主として外科系で手術後ドレーンなどから得ら れるものが多いと考学られる。諸家 ${ }^{10111}$ の指摘するよ 万に, 術後の感染予防目的の抗生剂第一選択として, 黄色ブドウ球菌に活性の低いいわゆる第三世代七フェ ム剂を使用している場合の少なくないことが，MRSA の誘導を惹起していることが示唆される.

喀痰由来の黄色ブドウ球菌も, CET, $\mathrm{CMZ}$ の感受性 率は低く, 呼吸器感染では MRSA が増加しているこ とがうかがえる。 また，血液から分離された本菌のう ち MRSA は40\%強を占めており, compromised host に抢ける敗血症に本菌が関与していることが推測され る.耳鼻咽喉科, 眼科検体由来の本菌は, 感受性は良 好であり，急性感染症の起炎菌が多数らくまれること によると考えられる.

尿由来の本菌が，最も高感受性を示しており，21株 中 MRSAは 1 株も認められなかった. DMPPCも 90.5\%と高感受性率を示している.ただし, PCG， $\mathrm{ABPC}$ は, 他の検体由来のものと同様㴗とんど全株が 感受性を示していない。

これらの尿検体由来の黄色ブドウ球菌につき，その 分離形態および臨床的背景を検討した。本菌は複数菌
感染菌として分離される場合が多く, 泌尿器科入院患 者 7 例の複数菌例のらち 3 例は尿道カテーテル留置例 であった。これらのことから, 本菌は尿路に対しては, 日和見感染として侵入することはあっても，病原性は 強くないことが示唆される。また，そのほとんどが MSSA (Methicillin sensitive Staphylococcus aureus) であることから, MRSA は尿路に対しょり定着性に乏 しいものと考えられる.

以上の成績から, 黄色ブドゥ球菌は主として膿, 浸 出液，喀痰などから分離され，これらのうち $30 〜 40 \%$ がMRSA であること, 敗血症の起炎菌としての黄色 ブドゥ球菌のらち $40 \%$ 強が MRSA であること, 尿由 来の本菌は，ほとんどが MSSA であり，その分離頻度 も低いことが示された。これらの検討結果から，外科 系の各科に打いては，術後感染における MRSA の関 与を未然に防ぐよう努力することの肝要性が結論づけ られた。

\section{結 語}

最近 1 年間に当院で分離された黄色ブドウ球菌の薬 剂感受性につき，由来検体別に集計した。また，黄色 ブドウ球菌の分離された尿路感染症につき，その臨床 的背景につき検討した，以下の成績が得られた。

（1）黄色ブドウ球菌に対する薬剂別感受性率は MINO, CMZ, CET の順に高かった。

（2）MRSA（メチシリンセフェム耐性黄色ブドウ球

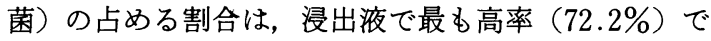
あり, 次いで血液 $(41.9 \%)$, 喀疢 (37.8\%)の順であっ た。尿では, MRSA は 1 株もみられず, DMPPC, CET, $\mathrm{CMZ}$ とも高感受性率を示した。

全検体ををとめると MRSA は $31.3 \%$ 占めてい た.

（3）尿由来の黄色ブドウ球菌は，ほとんどが入院患 者でみられ, 複数菌感染とし分離されるものが多かっ た.

\section{文 献}

1）横田健：MRSAの耐性機構からみた対策. Prog. Med., 5, 2679-2684, 1985.

2）島田 馨, 安達桂子, 田中喜久子, 上条化子, 佐々

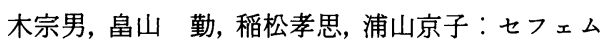
を含む多剂耐性黄色ブドゥ球菌の分離状況と41抗 菌剂に対する感受性. Chemotherapy，31, 835-841, 1983.

3）五十嵐英夫, 藤川 浩, 宇佐美博行：トキシック・ ショックシンドローム. 医学のあゆみ, 131, 945-950, 1984. 
4) Seligman, S.J. and Hewitt, W.L.: Resistance to penicillins and cephalosporins. Antimicrobial Agents and Chemotherapy, 1964, 387-391, 1965.

5) Novick, R.P. and Bouanchaud, D.: Extrachromosomal nature of drug resistance in Staphylococcus aureus. Annals New York Academy of Sciences. 182, 279-294, 1972.

6) Gravenkemper, C.F., Brodie, J.L. and Kirby, V. M.M.: Resistance of coagulase-positive staphylococci to methicillin and oxacillin. J. Bacteriol., 89, 1005-1010, 1965.

7) Collins, J.K., Mader, J.T. and Kelly, M.T.: Resistance of methicillin-resistant Staphylococcus aureus to third generation cephalosporins.
J. Infect. Dis., 147, 591, 1983.

8) Seligman, S.J.: Penicillinase-negative variants of methicillin-resistant Staphylococcus aureus. Nature, 209, 994-996, 1966.

9）紺野昌俊：MRSA 感染症の問題点. 感染症, 18, 137-144, 1988.

10）小西敏郎, 平田 泰, 平田 勝, 出月康夫, 奥住捷 子：消化管手術後 MRSA 感染症. 感染症, 18, 155-159, 1988.

11）横田 健：メチシリン・セフェム耐性黄色ブドウ 球菌（MRSA）とコアグラーゼ陰性ブドウ球菌 (CNS)遺伝的耐性株の耐性機構と対策. シンポシ ウム I, 第36回日本化学療法学会総会 (神戸) 講演 抄録, 1988 .

（1989年 1 月 30 日受理，特別掲載） 